\title{
Article
}

\section{Legitimating space: art and the politics of place}

Robinson, DW

Available at http://clok.uclan.ac.uk/12302/

Robinson, DW ORCID: 0000-0002-0729-5011 (2013) Legitimating space: art and the politics of place. World Art, 3 (1). pp. 121-139. ISSN 2150-0894

It is advisable to refer to the publisher's version if you intend to cite from the work. http://dx.doi.org/10.1080/21500894.2013.777848

For more information about UCLan's research in this area go to http://www.uclan.ac.uk/researchgroups/ and search for < name of research Group>.

For information about Research generally at UCLan please go to http://www.uclan.ac.uk/research/

All outputs in CLoK are protected by Intellectual Property Rights law, including Copyright law. Copyright, IPR and Moral Rights for the works on this site are retained by the individual authors and/or other copyright owners. Terms and conditions for use of this material are defined in the policies page.

\section{CLoK}

Central Lancashire online Knowledge www.clok.uclan.ac.uk

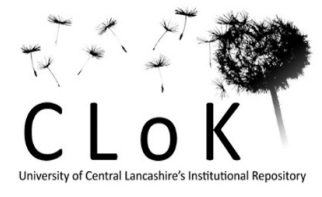




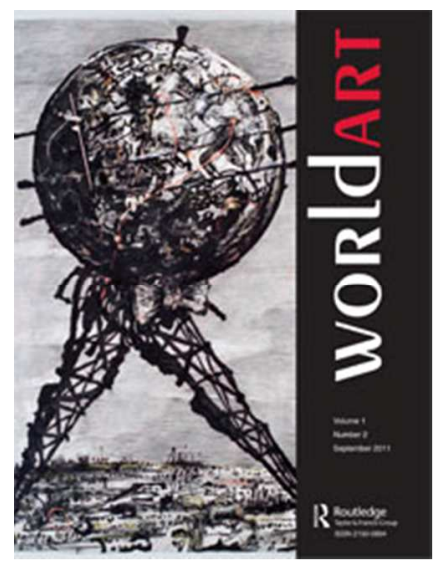

\section{Legitimating Space: Art and the Politics of Place}

\begin{tabular}{|r|l|}
\hline Journal: & World Art \\
\hline Manuscript ID: & Draft \\
\hline Manuscript Type: & Research Articles \\
\hline Date Submitted by the Author: & n/a \\
\hline Complete List of Authors: & $\begin{array}{l}\text { Robinson, David; University of Central Lancashire, School of Forensic and } \\
\text { Investigative Sciences }\end{array}$ \\
\hline Keywords: & Legitimation, rock-art, graffiti, Chumash, India, Barcelona, space, place \\
\hline & $\begin{array}{l}\text { Rock-art, graffiti, and other emplaced works of art bring people together at } \\
\text { specific places. Art allows for encounters between people in their absence, } \\
\text { and thus presents a range of possibilities for making statements about } \\
\text { specific places and those who occupy or visit. This opens the possibility for } \\
\text { issues of legitimation to become implicitly or explicitly expressed. However, } \\
\text { the legitimate use of space, and the legitimate employment of art, can vary } \\
\text { drastically across different contexts. } \\
\text { Here, I discuss a range of different strategies of art and legitimation in } \\
\text { three case studies from India, California, and Spain. }\end{array}$ \\
\hline & \multicolumn{2}{|l}{} \\
\hline
\end{tabular}


Legitimating Space: Art and the Politics of Place

\author{
David W. Robinson \\ University of Central Lancashire
}

\begin{abstract}
Rock-art, graffiti, and other emplaced works of art bring people together at specific places. Art allows for encounters between people in their absence, and thus presents a range of possibilities for making statements about specific places and those who occupy or visit. This opens the possibility for issues of legitimation to become implicitly or explicitly expressed. However, the legitimate use of space, and the legitimate employment of art, can vary drastically across different contexts.

Here, I discuss a range of different strategies of art and legitimation in three case studies from India, California, and Spain.
\end{abstract}

\title{
Key Words: Legitimation; rock-art, graffiti; Chumash; India; Barcelona; space; place.
}

"Every authority system tries to cultivate a belief in its legitimacy" (Zelditch andWalker 2003, 217).

In this paper, I am concerned with how art plays a role in strategies of claiming legitimate use of specific places. In an overview of psychological perspectives on legitimation, Tyler $(2006,378)$ opines that a "legitimating ideology is a set of justifications or 'legitimizing myths'... that lead a political or social system and its authorities and institutions to be viewed as normatively or morally appropriate by the people within the system." This is a good definition of the term 'legitimation'. For art that exists as a material medium, location in society is important when considering its social significance. Archaeological approaches to art are particularly adept at analyzing art's relation to place at multiple scales. Portable art found in archaeological deposits is 
amenable to stratigraphic analysis. Rock-art, and other forms of marking static surfaces fixed in place, allow for detailed spatial considerations, from the micro-topography of the surfaces themselves, to the embodied space where the artist applied the art, to the immediate environment of the artwork (i.e. the 'site'), on out to the wider landscape and world of human movement. The value of spatial analyses is to develop understanding the place of art in the social world for both the makers of the art and the communities who encounter it.

In a recent overview, Corbey et al (2008) argue that the Critical approach is one way that archaeologists profitably approach art: the authors $(2008,362)$ define this Critical approach to mean that, "art reflects, legitimizes or criticizes power relations." Although they do not explicitly state it, their approach to art is closely allied to the established literature of Critical Theory with its concern with power and the symbolic (for instance, in archaeology see Leone et al. 1987). As Bourdieu (1989, 21) points out, “...symbolic relations of power tend to reproduce and to reinforce the power relations that constitute the structure of social space". While Bourdieu's analyses of social space, power, and legitimacy often deal with the abstract and the textual, rock-art and other forms of emplaced marking exist in the physical, material world, and thus are manifestations of social power with discursive roles additional to or entirely beyond text.

Chippindale and Nash (2004) have shown that images such as rock-art are fixed in place and are full of meaning, but that meaning can be altered through changing circumstance. As such, art that is fixed in place is particularly amenable to strategies of legitimation and the maintenance of power related to those places where the art is located. Even more importantly, issues of legitimation can be manipulated, challenged, or contested though time. This is not to say that the field of power Bourdieu speaks of is any less a 'real world' phenomenon; however, issues of legitimacy are not only about establishing and maintaining power structures, but equally about transforming power relations, challenging claims of authority, and contesting claims of legitimacy.

As Gell (1998) and others intimate, art allows for encounters between people in their absence, and thus presents a range of possibilities for making statements about specific places and those who occupy or visit those places. This opens the possibility for issues of legitimation to become implicitly or explicitly expressed via place marking. 
These issues are not limited to prehistoric or anthropological contexts. In modern urban situations, Kwon $(2002,99)$ argues that public art often is embroiled within larger contradictions within local communities, so that "the work itself becomes a site of contestation over what constitutes something as public." An example of this is the Tilted Arc installation, a large metal installation placed in the Federal Plaza in New York from 1981-1989 which elicited vehement controversy, leading to public hearings, lawsuits and media debates (Kwon 2002, 57). From those who sponsor the art, to the artists, to those affiliated with the space where the art is placed, to those who encounter the art, different and perhaps incongruent motivations and understandings can lead to contestations. These disputes bring into focus issues of authority, claims of legitimacy, and social control. At the same time, legitimate uses of space, and the legitimate employment of art, can vary drastically across different temporal and societal contexts. By looking at the space of art, and considering it from a Critical Theory approach particularly focusing on issues of legitimacy, divergent interpretations arise that allow for appreciations of detail and difference. This approaches stands in marked contrast to some theoretical approaches to rock-art in particular that reify theoretical models and universal assumptions (see Whitley 1998; Winkelmann 2002). In the following sections, I document different strategies of art, place, and legitimation in three areas; a hunter-gatherer context in California; a transition from hunter-gatherer to Neolithic in India; and an urban example from modern Barcelona, Spain. Divergent narratives emerge, showing different employments of art as a tool of legitimacy and its contestation.

\section{Legitimating Power: Hunter-Gatherers, rock-art, and legitimacy.}

For hunter-gatherers who practice fusion/fission or seasonal transhumance, moving through the landscape entails encounters with rock-art at places in a transient fashion. Work that I have been conducting in South-Central California (Robinson 2004, 2007, 2010a, 2010b, 2011; Robinson et al. 2010; Robinson and Sturt 2008) has looked closely at ideologies of myth and agency seen in hunter-gatherer rock-art through careful consideration of the visual presence that rock-art had within indigenous society by examining its location in relation to how people moved through the landscape and the type of activities that occur within view of the art. In particular, I have focused upon the 
rock paintings of the Chumash, a complex hunter-gatherer linguistic group that occupied the region from the Santa Barbara Channel inland to the semi-desert environments of inland and interior regions. The Chumash developed a hierarchical society with integrated political and ceremonial elites (known from the documentary sources as the 'antap) that included village chiefs and many other ceremonial officials. Chumash society also included craft specialists and people whose identities were often linked to their skill: control of trade, wealth, and storable food were particularly important for political authority and ceremonialism, which in turn was underpinned by allusions to myth and to the supernatural as a means to legitimate indigenous institutions and relations of power (Gamble 2008; 2012).

The pictographs made by the Chumash are amongst the most spectacular and vivid rock-art found anywhere in the Americas (Grant 1965). These pictographs are typically found on rock formations associated with springs and other water sources. It is well established that for the Chumash and other neighbouring groups, watery locales were considered to have attendant watery beings, birds, or other animals; the rock was ascribed a semi-dormant ancestral agency as the outcrops were often considered to be mythological animals turned to stone in mythic times while rock-art was often attributed similar notions of supernatural potency (see Robinson 2004; 2010b). Pictographs were therefore considered images of power, able to influence anyone who happened to be within close proximity.

Surveys across Chumash territories of South-Central California show a pervasive association between pictographs and food-processing facilities, especially at sites known as K-locales. K-locales are sites having evidence of food preparation and cooking, especially with numerous bedrock mortars - conical hollows made on rock surfaces within which different foods were pounded in flour-like meals (see Jackson 1991; Robinson 2010a). Comprehensive survey data from three Chumash landscapes - the Sierra Madre ridge, the Carrizo Plain, and the San Emigdio Hills—-show a remarkable correlation between pictograph locations and K-locales (see Table 1). In other words, sites with large numbers of bedrock mortars are invariably where pictographs are displayed, while sites with few or no bedrock mortars rarely have pictographs present. This phenomenon is widespread throughout south-central California, with many instances 
of the placement of art immediately adjacent to or within the general confines of bedrock mortar food processing stations (Robinson 2011). In one study (Robinson 2010a), trail network, visibility, and 3-dimensional analyses (Figure 1) showed that pictographs and the features on which they were placed were encountered and seen regularly during the course of normal daily movement through the landscape.

As evidenced by the bedrock mortars, the locations were places where processing of staple wild seeds and nuts took place. The Chumash (as well as most other huntergatherer communities across south-central California) engaged in a 'delayed-return' subsistence economy; storable foods were central to subsistence (see Barnard and Woodburn 1988). Bedrock mortar stations were transiently used but crucially important localities, as acorns and other nuts and seeds were vital foods. Acorns were the most important staple, storable for two years or more, traded widely, and fundamental for daily sustenance. They were also part of conspicuous displays in events such as fiestas, mourning ceremonies, and other public events (Gamble 2008). At bedrock mortar sites, acorns and other foods were pulverized with a pestle. These sites are ubiquitous and the most common type of archaeological site found in California. However, ethnographic sources indicate that bedrock mortars were female work stations, with the processing of food labour intensive and time consuming process (Jackson 1991). It therefore has been argued by many scholars that women were tethered to bedrock mortar stations during seasonal periods of intensive food production and that their labour underpinned the economy of California society (Jackson 1991; Morgan 2009).

Recent excavations at Chumash pictograph sites in the San Emigdio Hills has produced evidence clearly indicating that a wide range of social activities were conducted at K-locales by all members of the local hunter-gatherer communities (Robinson et al 2010; Robinson and Sturt 2008). This indicates that in addition to women's work spaces, men and children also participated in seasonal activities at these sites. Sites with many bedrock mortars were obviously places for seasonal aggregation by multiple family groups, with extensive production and storage of acorns plus other foods taking place; they also were places where significant time and energy was expended, making them places of social interaction. 
The making of rock-art at such places drew upon notions of the past as places redolent with mythological power; it is likely that for those who made the art, the very act of engaging with such places served to make legitimate the local use of that place while reifying the ontological foundations of society. As mentioned above, ethnographic sources detail a widespread ideology that stresses the ambivalent power resident at rockart sites (Robinson 2010b). Rock-art thus focused intently on point specific locales of value in terms of reliable water, food availability, and the necessary bedrock for bedrock mortar usage (Robinson 2007). Importantly, surplus production of acorns and other storable foods generated wealth among local populations, enabling participation in regional exchange and ceremonial group events; it ultimately underpinned the hierarchical nature of Chumash society.

Displays of rock-art imagery were therefore intentionally placed at the center of Chumash subsistence production and social gatherings (Figure 2). Those making the art would have drawn upon widespread myths and as well as notions of power at these same locales to justify their own standing as persons of authority within indigenous society. The placement of rock-art made visible the ontological basis of these notions, simultaneously displaying authoritative negotiation with the resident powers. The art thus legitimated the power structure of society, drawing upon mythology and concepts of supernatural power to embellish the most significant places where subsistence and community came together in specific circumstances of food processing and storage.

\section{Legitimating Transitions: from Mesolithic to Neolithic, Hiregudda, India}

While it is clear that, in Chumash contexts, mythic narratives and stories of agency inhabiting natural places was fundamental to maintaining legitimacy, currently temporal data are insufficient to track that narrative in detail through time. In this section, I turn to a case study where spatial information can be supplemented with chronological data to document changing strategies of legitimation. Here, I turn to the wider environs of Hiregudda Hill, in the state of Karnataka, in the South-Asian Indian sub-continent.

Hiregudda Hill and its environs are an ideal landscape in which to consider changing dynamics of rock-art, its placement, and strategies of legitimation (Figure 3) (see Robinson et al. 2008). As in California, hunter-gather art focuses upon point 
specific locales. Mesolithic sites, such as Birappa, are found on granitic outcrops on the Deccan Plateau, characterized by the manufacture of small tools using quartz stone along with red pictographs that emphasize tear-drop torso anthropomorphs, insects, and wild animals (Figure 4) (Robinson and Koshey 2004; Robinson and Ramadas 2004a). In contrast, with the subsequent emergence of the Neolithic, rock-art locations changed to the adjacent doleritic hills, dominated by petroglyph carving rather than painted pictographs. Survey across the landscape (Robinson and Ramadas 2004b) has shown that the majority of the art was placed on the doleritic crests, including hill top, ridge, and saddle locations, covering swaths of rocky terrain, integrated into settlement areas and axe workshop locations. Chronological analyses suggests an increasing use of bull motifs, with a change from narratives concerned with bulls in the singular, to compositional elements stressing multiple bulls, bulls forming symbolic formations, and the addition of anthropomorphic figures to preexisting bull motifs (Figure 5) (see Robinson et al. 2008).

. In stark contrast to the point-specific Mesolithic hunter-gatherer art, the art of Hiregudda dominates large swaths of the habitable terrain and is characterized by this bull imagery. It is clear from excavations at Birappa (see Robinson and Koshey 2004) that there was a renewed use of that locality in the Late Neolithic but that it continued to be a site where small blade tools almost identical to those in the earlier Mesolithic were manufactured. Shipton et al. $(2012,171)$ have pointed out that this may indicate that Birappa was favoured by hunter-gatherer groups who lived alongside agricultural communities in the region during the Neolithic: this calls into question the landscape setting for cattle imagery. Indeed, this imagery likely differentiated those communities who adopted cattle from those who did not. The practice of herders differentiating themselves from hunter-gatherers by elevating the status of cattle owners is commonly seen in similar circumstances where herders and hunter-gatherers live side-by-side (see Smith 1998). Smith $(1998,213)$ argues that it "would take a major reorganization of the relations of production to allow hunters, even those capable of herding stock, to build the animals into the symbolic and ritual realm that is characteristic of pastoralists." Archaeological work in the Hiregudda region indicates that, for some communities, just this kind of reorganization took place as evidenced in in transformations from quartz to 
dolerite axe manufacturing, the introduction of cereals, and of course the incorporation of cattle. But, it may not have been universal, with different communities adopting Neolithic practices, while others retained hunting and gathering practices. Bull imagery therefore may have been an ideological means of legitimizing the use of hill top locations and dolerite needed for axe manufacturing through consistent and repetitive marking.

Changes through time indicate that the imagery may have played a role differentiating within Hiregudda society as much as to external others. The addition of anthropomorphic figures on bull and other animal images indicates that the human control of cattle was explicitly becoming narrated via the art. It is likely that these changes in rock-art correspond with the apparent increasing social inequality within society and the creation of powerful elites as Hiregudda society "underwent a further transformation becoming a more stratified society, constructing individualised monuments and becoming part of an intercontinental trade network" (Shipton et al.: 171). Rather than stressing the adopting of cattle, the new art may have reified the human control of bulls, thus shifting focus onto individuals who had the ability to acquire cattle rather than deifining community as a whole.

In this case, seen through time, the employment of art was transformative: power relations shifted, and art was employed in the creation different narratives. Earlier art was focused on specific scenes of the human form in relation to insects, wild animals such as deer and boar, plus fish, sometimes depicted with their heads cut off. Collectively, this art represents a concern with hunting and fishing practices. However, later art represented an entire new corpus of imagery, focusing on large domesticated animals and only latterly involving the human form, albeit in an entirely different style from Mesolithic tear-drop torso examples.

The very act of marking the extended landscape ultimately legitimated a transition to an ideology concerned with cattle in a pervasive and widespread visual format. Bull imagery indicates a new and emergent dominant metanarrative, highly visible to anyone moving through the landscape via transhumance practices that entailed habitual use of the terrain in a very different manner than that of hunter-gatherers. The widespread spatial patterning shows, I argue, the fundamental symbolic importance of cattle; the making of the art inculcated people into a Neolithic ideology. 


\section{Contesting Legitimating: graffiti in urban spaces}

So far, this discussion has touched upon aspects of legitimizing in non-western, nonmodern rock-art found at what has been termed 'natural places' by scholars such as Bradley (2000). In the final example, I examine art within a contemporary setting, the urban environment of Barcelona. Here, my work with Hector Orengo examined the spatial dynamics of a single alley in the medieval quarter known as St. Rock Street (see Orengo and Robinson 2008). Our research took an explicitly archaeological approach to graffiti and other uses of material culture to examine social discourse in a modern urban space.

Found at right angles to the busy Ramblas shopping and clubbing district, St. Rock Street is a narrow alley providing a short cut between major pedestrian thoroughfares. In the middle of the street, in a distinctive crook, is a niche with a statue of St. Rock. Our analysis, using map regression, aerial photography, and viewsheds indicate that the crook has its antecedent roots in the medieval period: importantly, the crook creates an area at the center of the street that is invisible from the street entrances (Figure 6).

Our documentation of the material culture and graffiti of the street showed a gradation of graffiti styles that changed along the axis of the street. The graffiti clearly changed in type, from the visible street apertures on towards the crook in the middle. First, at the entrances where pedestrian traffic is highest, 'quick graffiti', or monochrome tags, stencils, or stickers (Figure 7) were common. These types of graffiti can be applied with minimal time, requiring only a moment or two (see Ferrell 1993: 70-94). Further down the street, quick graffiti began to be complemented with more elaborate tagging, especially dual-chrome slap-ups. The slaps-ups were typically stylized signatures, requiring at least two cans of different colour paint and more time for application. Nearing the center of the street, polychrome pieces laced with social commentary and sarcasm were located in the areas of minimal visibility from the street apertures (Figure 8). These central pieces involved a greater variety of paint, or combinations of paint with stencils; they sometimes appear to have been outlined before painting. Thus, while the making of the art in the central point of the street required 
much more time, the shape of the street afforded that time because of the invisibility of the central point.

Thus the context for St. Rock Street graffiti making and viewing is one of gradating visibility; the apertures can only afford limited time to make graffiti while the crook in the middle affords a space where artists can find time to make more elaborate pieces, especially at night. At the same time, because the street's central location provided a short cut through the area of the Ramblas, it actually provided an audience for the artists. However, graffiti is illegal: the very act of making stands in opposition to mainstream authority. A series of statements challenging dominant authority was put forward by the graffiti artists, including critical commentary on the war on terror, globalism, separatist Catalan ideologies, plus issues of local street politics. People living on the street countered with removable banners to claim back the alley from the graffiti artists. As such, the graffiti of St. Rock Street can be seen as a form of anti-legitimacy and counter ideology. The invisibility of the space mirrors the anonymity of the artists in relation to the wider society, an anonymity that enhances a sense of unease that the graffiti itself promotes; the content of their messages and their unseen acts of painting challenge dominant discourse, thus contesting the normative claims of authority and legitimacy.

However, and perhaps ironically, graffiti operates within its own internal rules of legitimacy by standing in opposition to the dominant society and its claims of ultimate legitimacy and authority (Ferrell 1993). Certain rules of conformity appear to be at work, with a small percentage of the polychrome pieces overlain by subsequent graffiti, indicating a respect for more complex statements in the center of the street. By making the politicized and more 'artistic' works, status and hierarchy appear to have been in operation within the graffiti artist community. So, while the group as a whole stands in opposition to the mainstream through rule breaking, within their own sub-culture, rules of behaviour nevertheless prevail. The modern urban state, with its high population, has far more sub-cultures than did the local traditional communities discussed in the earlier examples. Contesting claims of authority and legitimacy bring about counter-culture challenges to authority and legitimacy. Like Kwon's (2002) Titled Arc example from New York, this example from Barcelona clearly entails the kind of contradictions he 
speaks of when considering public art within urban environments. Perhaps ironically, the elaborate pieces of St. Rock Street occupy the least visible locations of the three examples considered here.

\section{Discussion}

Bourdieu $(1989,16)$ is astute to point out that "the visible, that which is immediately given, hides the invisible which determines it". In the California rock-art, those who made the art made visible the unseen supernatural power imminent in certain natural features, lending an ideological impact to legitimacy. .In this classic example of a negative form of ideology, through manipulation of claims to supernatural potency and notions of danger, the artists placed themselves as arbiters between society and the supposed invisible menace inhabiting particularly vital locations that people had to occupy. On the other hand, the art may have legitimated the use of the place for the community, lending a sense of agency to the group rather than strictly to the artist's themselves. Certainly, the art made clear the power and authority of the artists to mediate these dangerous places. In Tyler's $(2006,378)$ psychological perspectives of legitimation, aspects of art and place worked together to justify indigenous institutions and to reinforce the social order. Equally, in India, the shift from point specific places and wild animal imagery to the embellishment of an entire landscape with domesticated animal imagery facilitated some communities to adopt a Neolithic way of life. Because of the sheer numbers of panels and individual elements, plus its wide distribution, the art likely was made by a significant segment of society. The making of the art made everyone participants in a new way of world making, both in the performative, visceral actions of making and afterwards through viewing it in daily routines.

Finally, and by contrast, the graffiti of St. Rock Street in Barcelona must be seen as antithetical to mainstream society. In one sense, it operates to undermine dominant claims of legitimation. On the other hand, it gains its own legitimacy, and therefore power, through its illegality and opposition as well as it ongoing presence in urban life. It gains ironic force and its own internal legitimacy through opposition to dominant forms of power discourse. 


\section{Conclusion}

Weatherford (1992) argues that the strategic goal of legitimacy is to provide a "reservoir of support" for institutions and authorities beyond the immediate self-interest of the larger populace. Emplaced art can play such a role in discourses of legitimization. In one sense, art legitimates world view, or sustains the ontological basis of society by making visible its underlying principles. On the other hand, such legitimation implicitly reifies the structure of society so that that authority can assert itself unencumbered by contesting views. In this sense, legitimacy is closely linked to ideology. In the nonwestern examples outlined above, society certainly did provide such reservoirs of support closely linked to the activities carried out on a day to day basis. Pictographs were presenced in the locus of food preparation, production, and storage at K-locale sites in California, places that provided the economic support for the ceremonial system arbitrated by elite members of society. Similarly, the widespread bull imagery of Hiregudda shows that a significant segment of the population would have been involved in making the art, and that certainly the entire populace would have seen it, therefore supporting narratives about the importance of cattle to the emergent lifeways of the Neolithic. The urban environment shows a different story. Even as there may be internal etiquette followed by the majority of graffiti makers, certainly no 'reservoir of support' for the tenets of mainstream society can be seen in the contested discourse exhibited by the graffiti. By taking a critical approach to emplaced art and strategies of legitimization, different case studies reveal radically different strategies undertaken by people in the past. Art can be employed towards different aspects of legitimation. This approach allows for data led interpretation rather than reifying models and presumptions of universality (Winkelmann 2002). By continuing to analyze art spatially, and continuing to consider its social context, the importance of art is appreciable through the archaeological approach.

\section{Acknowledgements}

I would like to thank John Robb and Elizabeth DeMarrais for the invitation to the SAAs in Memphis, as well as for this publication. I also thank the staff of the Wind Wolves Preserve in California for their support of my research, as well as the Rock Art 
Documentation Group and Rick Bury for permission to use his photograph. I thank Fraser Sturt and Julienne Bernard and all of the participants of the Enculturation Environments Project. I also thank my colleague Hector Orengo for our collaboration in Barcelona, as well as the crew of the Sanganankallu-Kupgal Archaeological Research Project in India, especially Ramadas.

\section{References}

Barnard, A., \& J. Woodburn. 1988 Property, Power and Ideology in Hunter-Gathering Societies: An Introduction. In Hunter and Gatherers: Property, Power, and Ideology. Eds. Tim Ingold, David Riches, and James Woodburn, 4-31. Oxford: Berg, Bourdieu, Pierre. 1989. Social Space and Symbolic Power. Sociological Theory $7(1): 14-25$.

Bradley, Richard. 2000. An Archaeology of Natural Places. Routledge, London. Chippindale, Christopher, and George Nash. 2004. Pictures in place: approaches to the figured landscape of rock art. In The Figured Landscapes of Rock art: Looking at Pictures in Place. Eds. Christopher Chippindale and George Nash, 1-36 Cambridge, Cambridge University Press.

Cobey, Raymond, Robert Layton, and Jeremy Tanner. 2008. Archaeology and Art. In $A$ Companion to Archaeology. Ed. John Bintliff, 367-379. Malden, Blackwell Publishing, Douglas, Mary (1966) Purity and Danger: an Analysis of Concepts of Pollution and Taboo. London: Routledge.

Ferrell, Jeff (1993) Crimes of Style: Urban Graffiti and the Politics of Criminality. New York: Garland.

Gamble, Lynn. 2008 The Chumash World at European Contact: Power, Trade, and Feasting Among Complex Hunter-Gatherers. Berkeley: University of California Press. - 2012. A Land of Power: The Materiality of Wealth, Knowledge, Authority, and the Supernatural. In Contemporary Issues in California Archaeology. Eds. Terry L. Jones and Jennifer E. Perry, 175-196. Walnut Creek: Left Coast Press. Gell, Alfred. 1998. Art and Agency: An Anthropological Theory. Oxford: Oxford University Press. 
Halsey, Mark and Young, Alison. 2006. “"Our Desires are Ungovernable”: Writing Graffiti in Urban Space, Theoretical Criminology (10)3: 275-306.

Kwon, Miwon. 2002. One Place After Another: site specific art and locational identity.

Cambridge, Massachusetts; MIT Press.

Jackson, Thomas L. 1991. Pounding Acorn: Women's Production as Social and Economic Focus. In Engendering Archaeology, Women and Prehistory. Eds. Joan M.

Gero and Margaret W. Conkey, pp., 301-325. Oxford, Blackwell.

Leone, Mark, Parker B. Potter, Jr., and Paul A. Shackel. 1987. Towards a Critical Archaeology. Current Anthropology 28(3): 283-302.

Morgan, Christopher. 2009. Optimal Foraging Patterns in the Sierra Nevada, Alta California. California Archaeology 1: 205-226.

Orengo, Hector, and David W. Robinson. 2008. Contemporary Engagements Within Corridors of the Past: temporal elasticity, graffiti and the materiality of St Rock Street, Barcelona. Journal of Material Culture 13(3): 267-286.

Peteet, Julie (1996) 'The Writing on the Walls: The Graffiti of the Intifada'. Cultural Anthropology 11(2): 139-59.

Riches, David. 1994. Hunter-Gatherer Structural Transformations. Journal of the Royal Anthropological Institute (N.S.) 1: 679-701.

Robinson, David W. 2004. The Mirror of the Sun: Surface, Mineral Applications, and Interface in California Rock Art. In Soils, Stones and Symbols: Archaeological and Anthropological Perspectives on the Mineral World. Eds. Nicole Boivin and Mary Ann Owoc, 91-106. London, University College London Press.

—. 2007 Taking the Bight Out of Complexity: Elaborating South-Central California Interior Landscapes. In Socialising Complexity: Structure, Integration, and Power. Eds. Sheila Kohrning and Stephanie Wynne-Jones, 183-204. Oxford, Oxbow.

_. 2010a Resolving Archaeological and Ethnographic Tensions: A Case Study from South-Central California. In Archaeological Anthropology: Understanding Similarities, Exploring Differences. Eds. Duncan Garrow and Thomas Yarrow, 84-109. Oxford, Oxbow. 
_. 2010b Land Use, Land Ideology: An Integrated Geographic Information Systems Analysis of the Emigdiano Chumash Rock Art, South-Central California. American Antiquity 74: 292-818.

- 2011. Placing Ideology: Rock Art Landscapes of Inland and Interior SouthCentral California. California Archaeology 3(1): 31-52.

Robinson, David W. and Jinu Koshy. 2004. Preliminary Report on the Excavations at Birappa Rock Shelter, In Sanganankallu-Kupgal Archaeological Research Project: 2003-2004 Preliminary Report. Ed. Nichole Boivin, 109-120. Project Archives. Robinson, David W. and Ramadas. 2004a. Birappa Rockshelter Rock Art, in Sanganankallu-Kupgal Archaeological Research Project: 2003-2004 Preliminary Report. Ed. Nichole Boivin, 325-34. Project Archives. - 2004b. Preliminary Report on the Rock Art of Hiregudda and Sannarachamma. In Sanganankallu-Kupgal Archaeological Research Project: 2003-2004 Preliminary Report. Ed. Nichole Boivin, 303-24. Project Archives.

Robinson, David W., and Fraser Sturt. 2008. Towards Articulating Rock Art with Archaeology: An Interim Report of the Pinwheel Cave Rock Art and Bedrock Mortar Complex (CA-KER-5836 \& -5837), Kern County, California. Kern County Archaeological Society Journal 10: 25-44.

Robinson, David W., Fraser Sturt, and Julienne Bernard. 2010. Enculturating Environments: Rock Art and the Interior of South-Central California. Antiquity 84:232, Project Gallery. Electronic document, http://antiquity.ac.uk/projgall/ robinson 323.

Shipton, Ceri, Michael Petraglia, Jinu Koshy, Janardhana Bora, Adam Brumm, Nicole Boivin, Ravi Korisettar, Roberto Risch, and Dorian Fuller. 2012. Lithic technology and social transformations in the South Indian Neolitich: the evidence from SanganakalluKupgal. Journal of Anthropological Archaeology 31: 156-173.

Smith, Andrew B. 1998. Keeping People on the Periphery: The Ideology of Social Hierarchies between Hunters and Herders. Journal of Anthropological Archaeology 17: 201-215.

Tyler, Tom R. 2006. Psychological Perspectives on Legitimacy and Legitimation. Annual Review of Psychology 57: 375-400. 
Weatherford, M. Stephen. 1992. Measuring political legitimacy. American Political Science Review 86: 149-66.

Whitley, David S., 1998. Cognitive neuroscience, shamanism, and the rock art of native California. Anthropology of Consciousness 9(1), 22-37.

Winkelman, Michael. 2002. Shamanism and Cognitive Evolution. Cambridge Archaeological Journal 12(1):71-101.

Zelditch, Morris and Henry A. Walker. 2003. The legitimacy of regimes. In Power and Status (Advanced Group Processes, Volume 20). Eds. Shane R. Thye and John Skvoretz, 217-249. Emerald Group 


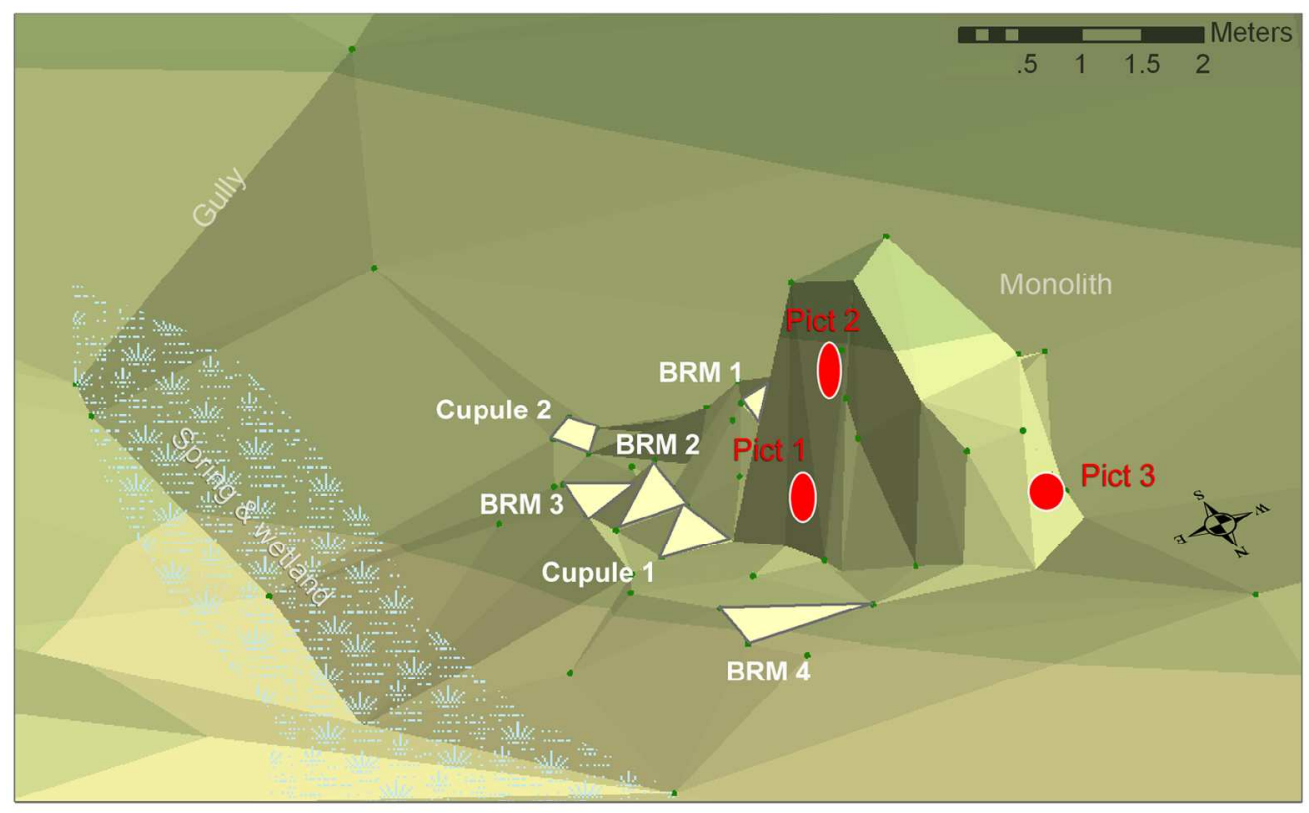

$152 \times 94 \mathrm{~mm}(300 \times 300$ DPI $)$ 


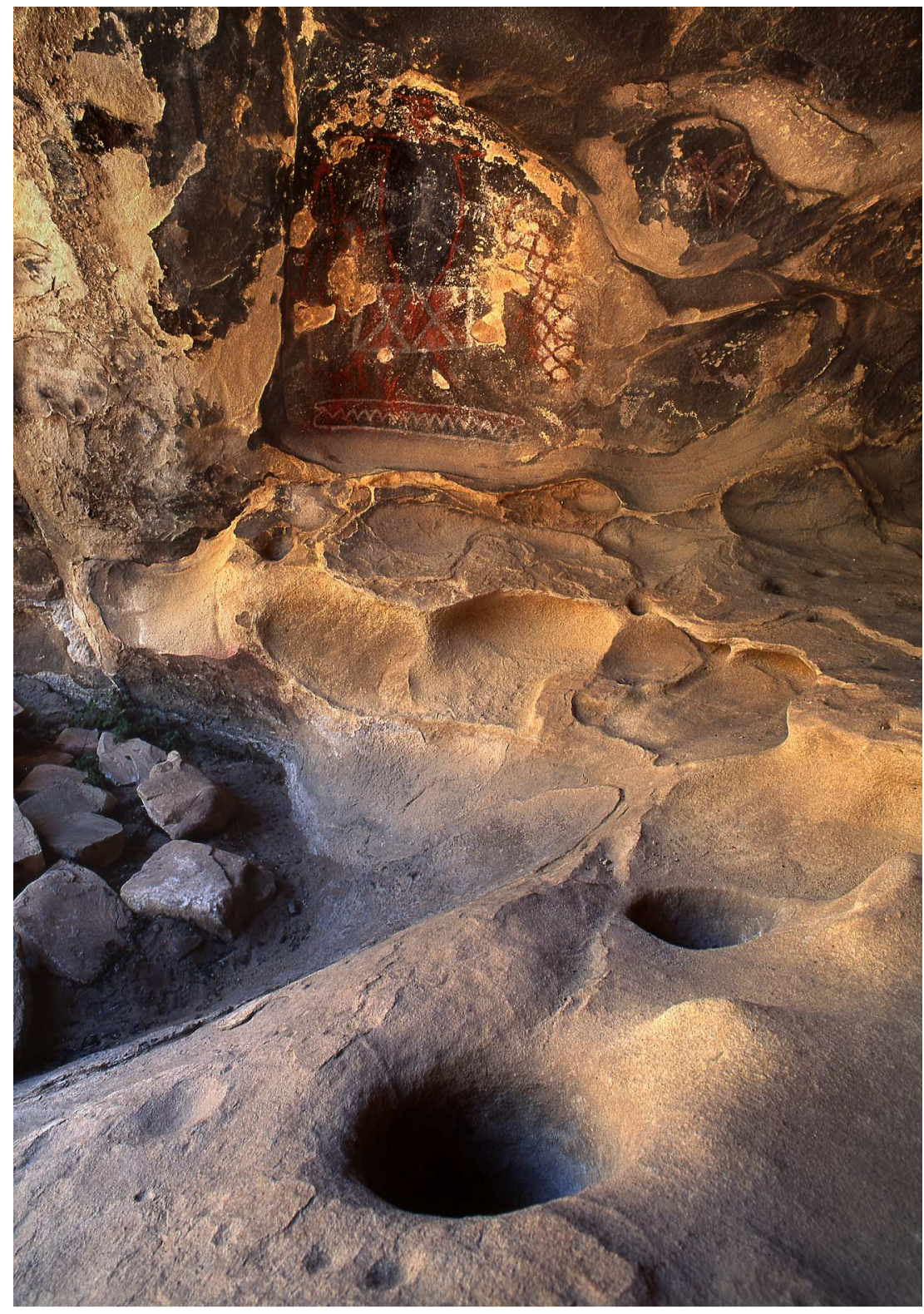

$177 \times 254 \mathrm{~mm}(300 \times 300 \mathrm{DPI})$

URL: http://mc.manuscriptcentral.com/RWOR Email: worldart@uea.ac.uk 

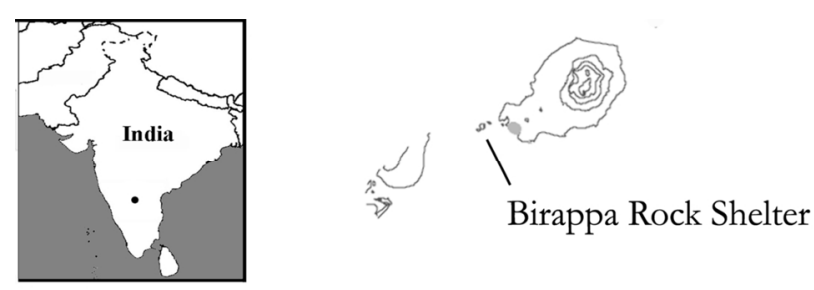

\section{1 kilometre}

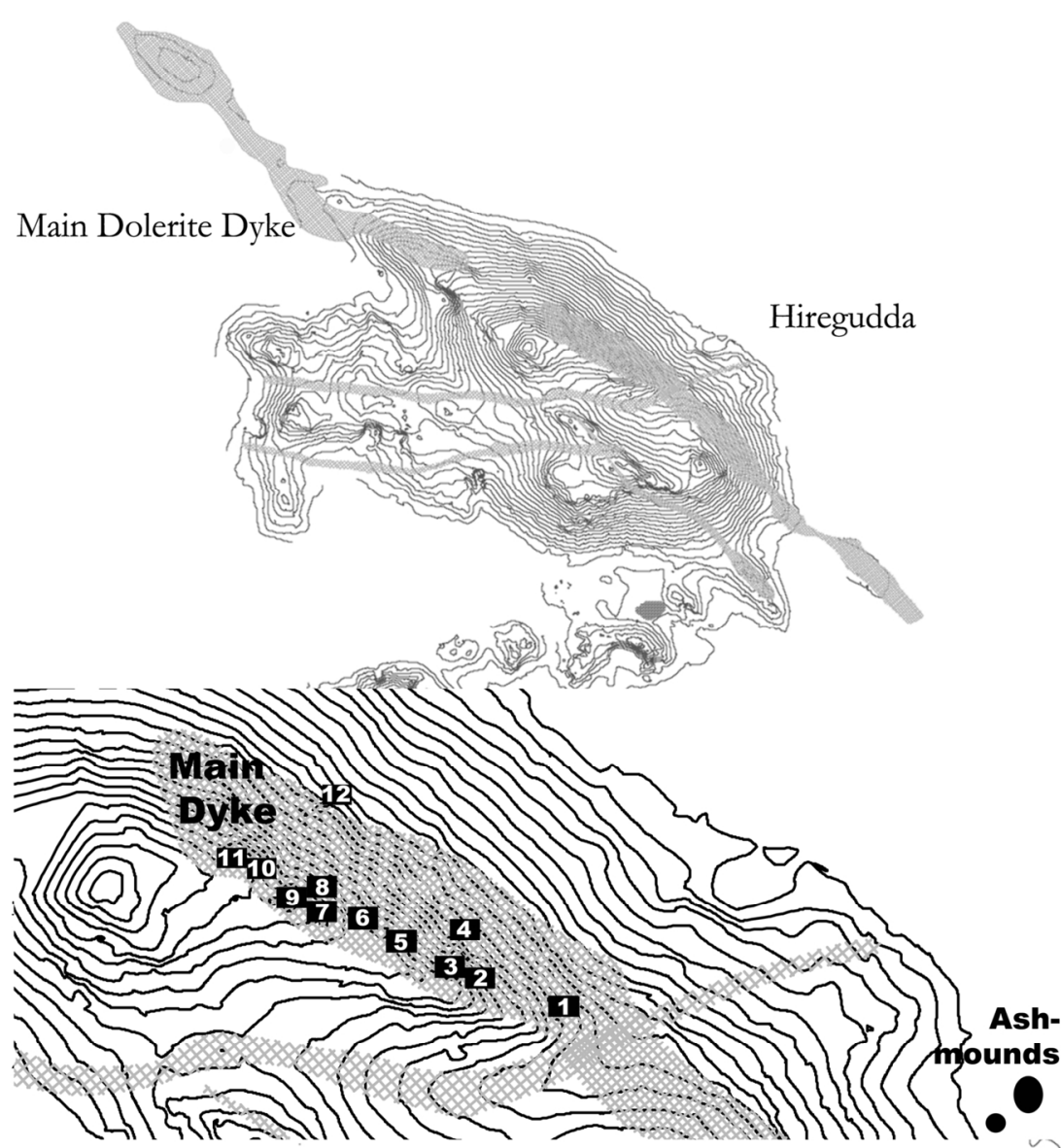

$144 \times 181 \mathrm{~mm}(300 \times 300$ DPI $)$

URL: http://mc.manuscriptcentral.com/RWOR Email: worldart@uea.ac.uk 

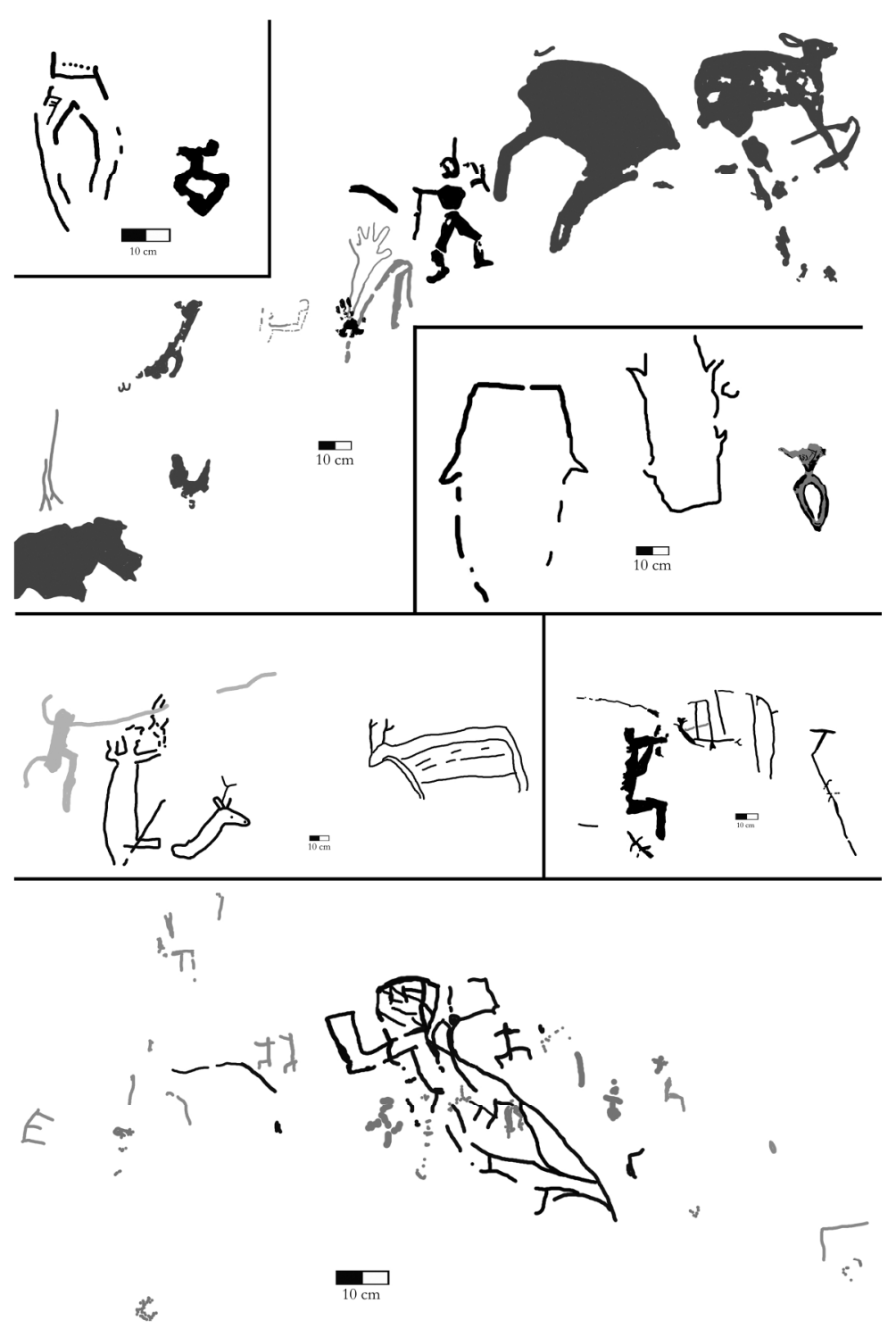

$184 \times 297 \mathrm{~mm}(300 \times 300$ DPI $)$

URL: http://mc.manuscriptcentral.com/RWOR Email: worldart@uea.ac.uk 


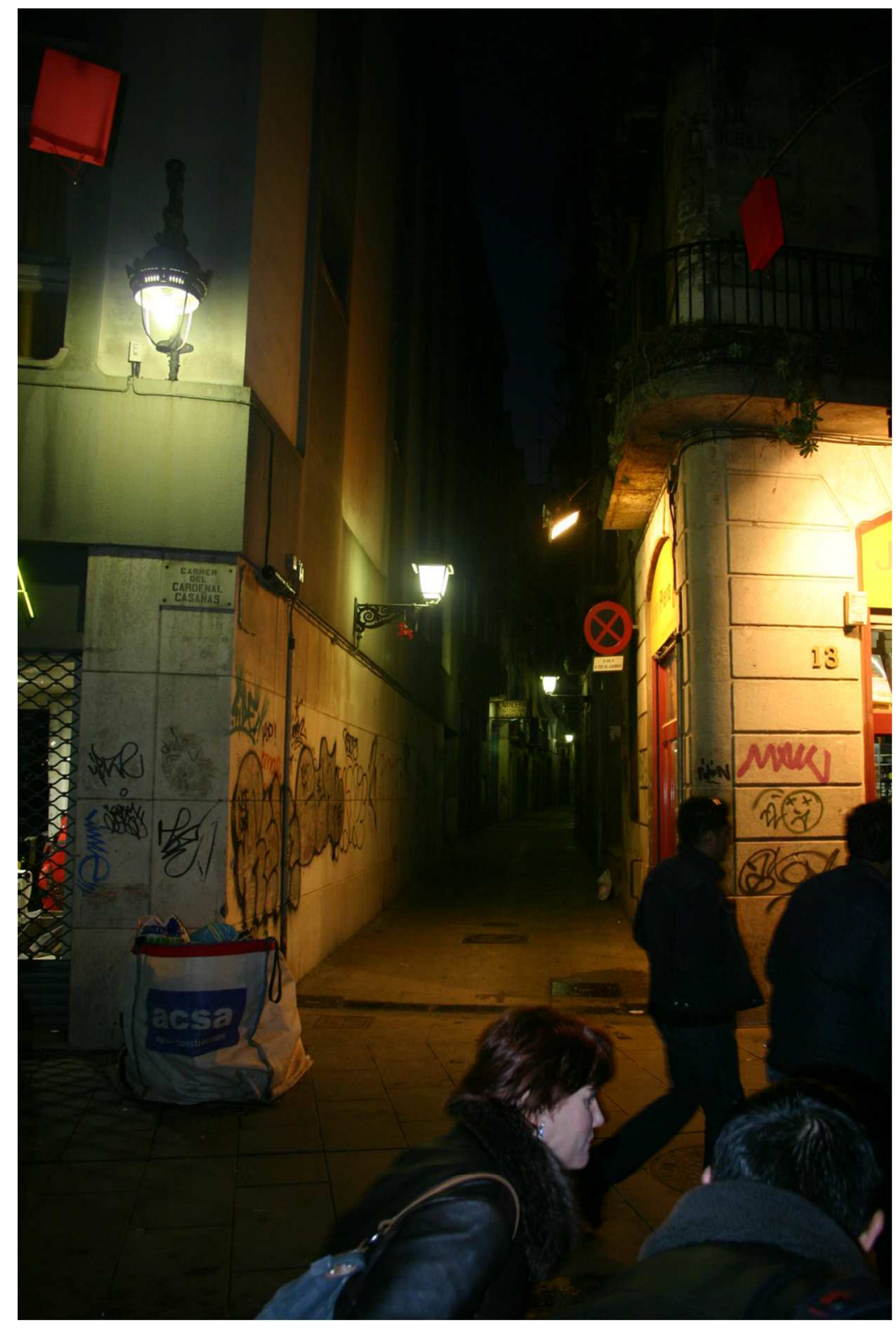

$144 \times 216 \mathrm{~mm}(180 \times 180 \mathrm{DPI})$ 


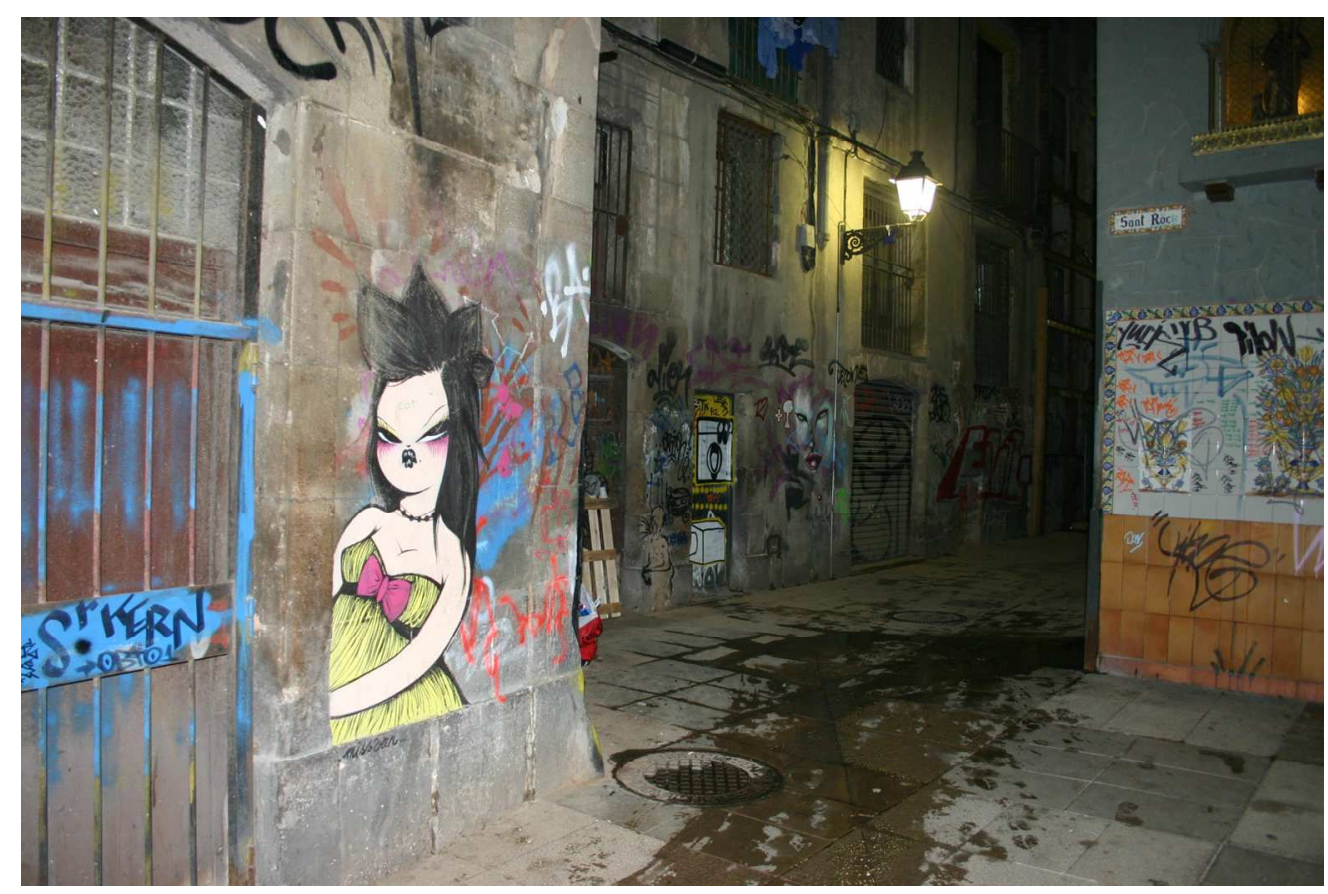

$216 \times 144 \mathrm{~mm}(180 \times 180 \mathrm{DPI})$ 
Table 1: Correlations between pictographs and K-locales/non-K-locales. Data collated from Tables 1, 2, and 3 in Robinson 2011.

Figure 1: 3-Dimensional reconstruction of Santiago K-locale, San Emigdio Hills. Note proximity of bedrock mortars to pictograph panels.

Figure 2: Photograph of Chumash pictograph panel and bedrock mortars at K-locale site known as Pool Rock in Santa Barbara backcountry. Photo by Rick Bury.

Figure 3: Map of Hiregudda Hill and environs. Note location of Birappa Shelter where Mesolithic pictographs are found. Neolithic and later petroglyphs are found on most areas of the main dolerite dyke on Hiregudda.

Figure 4: Pictograph elements at Birappa Shelter.

Figure 5: Bull elements from Hiregudda Hill.

Figure 6: Viewshed analysis of St. Rock Street, Barcelona.

Figure 7: View of graffiti at entrance to St. Rock Street.

Figure 8: View of graffiti at the centre of St. Rock Street. 
Non-K-loca K-locales

$\begin{array}{lrr}\text { Sites witho } & 213 & 8 \\ \text { Sites with } F & 16 & 44\end{array}$

6

7

8

9

10

11

12

13

14

15

16

17

\section{Pictograph and K-locale/non} Total date from Chumash surveyer and San Emigio Hills.

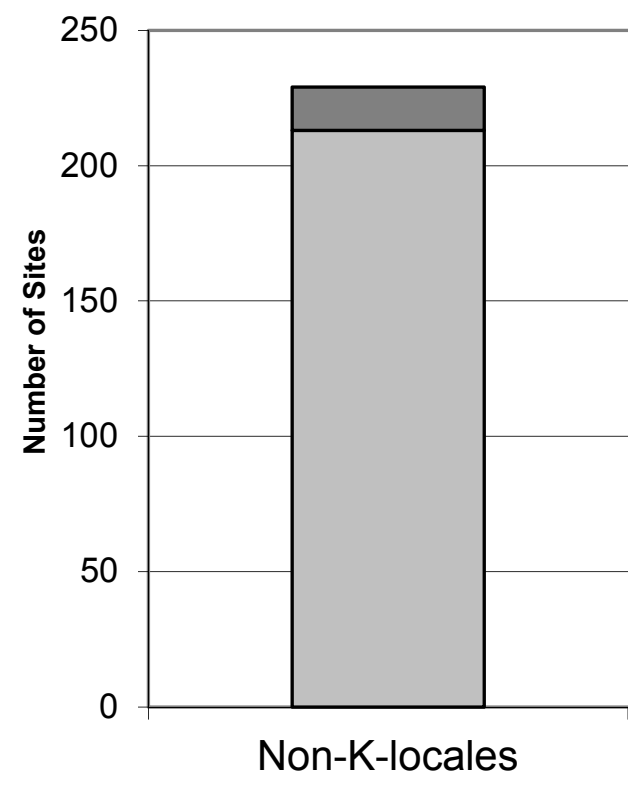

URL: http://mc.manuscriptcentral.com/RWOR Email: worldart@uea.ac.uk 


\section{-K-locale correlations:}

d areas, Sierra Madre Ridge, Carrizo Plain,

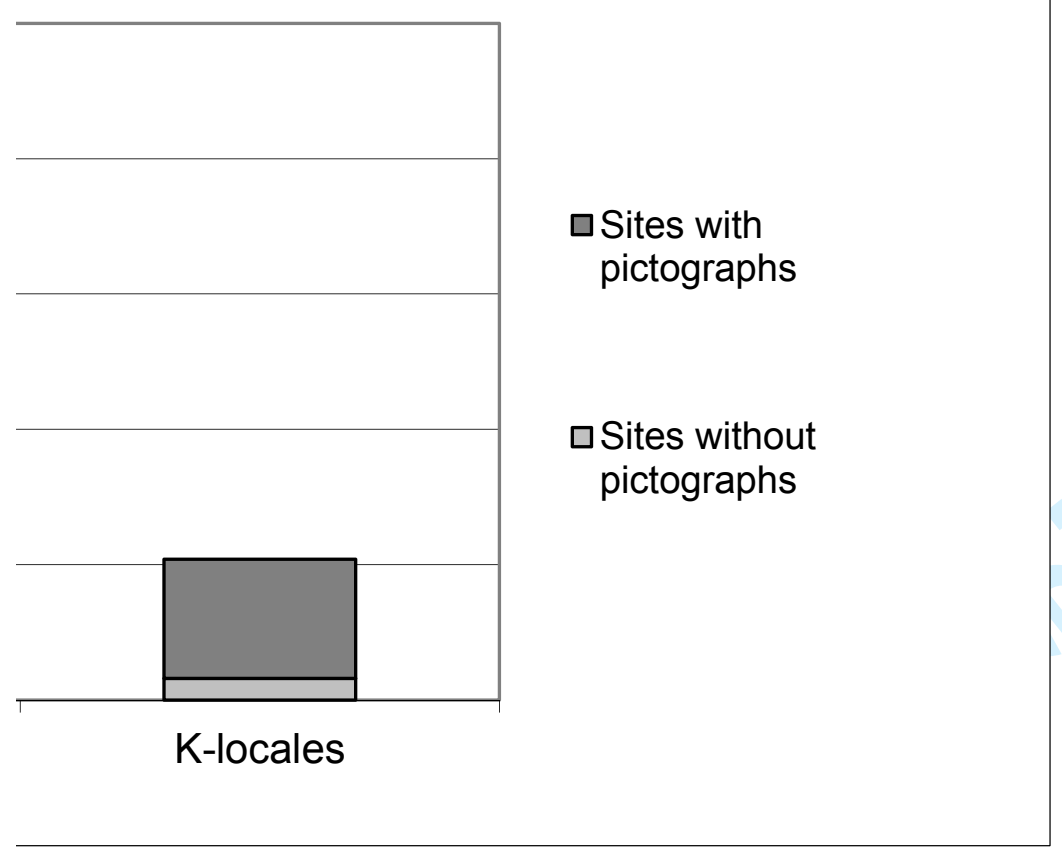

URL: http://mc.manuscriptcentral.com/RWOR Email: worldart@uea.ac.uk 